\title{
Evaluation of Irrigation Water Price Addition on Productivity of Agriculture Section in Iran (Case: Kashan Region)
}

\author{
Mohsen Tarafdar \\ Accounting \& Management Department, Kashan Branch, Islamic Azad University, Kashan, Iran \\ Email: M.tarafdar@iaukashan.ac.ir
}

Received 1 January 2015; accepted 17 January 2015; published 22 January 2015

Copyright (C) 2015 by author and OALib.

This work is licensed under the Creative Commons Attribution International License (CC BY). http://creativecommons.org/licenses/by/4.0/

(c) (i) Open Access

\begin{abstract}
The shortage of irrigation water is one of the most important problems which Iran is facing. Irrigation water pricing is one of the economic approaches to manage irrigation water consumption and using it efficiently. This study purpose is to evaluate the effect of irrigation water price induction on productivity of agriculture section in Iran (case: Kashan). This study is an application development in terms of objective and a post-event in terms of the study design, and is descriptive in terms of conclusion. The study results show that during study period (2006-2010), irrigation water price has risen in Kashan region. But this leads not only to increasing average cultivated land per a farmer, but also to increasing crops and garden products' monetary productivity. It means that Iranian government can use irrigation water price induction as a tool for increasing productivity in agriculture section in Iran. In addition, crops and garden products have different productivities. Results also show that dill and apricot have the highest productivity in all crops and garden product in the region respectively.
\end{abstract}

\section{Keywords}

Productivity, Irrigation Water, Price, Crops, Garden Product, Kashan Region

Subject Areas: Economics

\section{Introduction}

The world is currently living a water crisis. For more than one billion people in the world, clean water supplies are not available. Until 2025, more than half of the world's population will live in countries where over 40 percent of their re-usable water resources are abolished. Although water covers three-quarters of the Earth's surface, only 3 percent of the world's resources are freshwater and usable for agriculture. For the purpose of expanding 
agricultural lands, the restrictions of water provision are the following - the deficit of renewal water in the world, the high costs and complexities of projects for water provision, the emergence of new competitors in the field of water consumption and the reduction of water allocation in agriculture due to the increase in drinking and industrial requirements, the demand of greater attention for the biosphere and the reduction of usable water supplies in agriculture, as a result of loss in water quality (dissolved salts in water). Thus, the only way to meet the increasing demand for food is the effective use of water resources acquired for agriculture by using less amounts of water to get larger volumes of products [1]. However, the above mentioned way of water consumption is not the only one; here, the selection of crops is also very important. Along with the world water shortage (as the most important basic matter/factor in the field of agriculture), in various continents the uneven distribution of water is also an additional problem next to this crisis. Asia with 60 percent of world's population is secured only with 30 percent of water resources. Iran's population is more than 1 percent of the world's population. Yet, only 0.36 percent of re-usable freshwater is available to the country and is unevenly distributed [2].

Based on Iran's comprehensive project surveys, the renewal water resources of the whole country are around 130 billion $\cdot \mathrm{m}^{3}$, of which 89.5 billion $\mathrm{m}^{3}$ are used in agriculture, industry, mining and for household consumption, of which around 83 billion $\cdot \mathrm{m}^{3}$ (or 93 percent) are given to agriculture [3].

On one hand, agriculture, which is the main consumer of recycled fresh and re-usable waters, forms 18 percent of GNP and 25 percent of employment and secures 85 percent of public food; it forms 25 percent of non-oil exports and 9 percent of raw materials used in industry. On the other hand, Iran is located in arid and semiarid climatic conditions in the region, where the average yearly precipitation rate is $261 \mathrm{~mm}$ (the calculation of the average annual precipitation is $860 \mathrm{~mm}$ ). And the average annual volume of re-usable water per capita is 1900 $\mathrm{m}^{3}$ (when the world's average annual volume of re-usable water per capita is $7500 \mathrm{~m}^{3}$ ). From which, more than ever, the necessity to pay attention to water deficit is felt. The issue of water pricing is very important for the effectiveness in agricultural sector.

During evaluation of irrigation water factors and efficiency, the presentation of its economic and social consequences is essential. This is important insofar that irrigation not only brings economic consequences, but also has the social issue. In Islamic Republic of Iran water is equated with life. It plays a major role in the development of communities, enhances prosperity, and decreases migration and reproduction of population. Thus, apart from its economic importance, in water tariffs, it is also essential to see the social image. In the International Conference of Freshwater 2001, which was held in Bonn, the pricing of water was represented as just one tool for water management purposes, and the support and payments of financial and operative expenses of water were on focus. The most important measure of the conference was the fact that water is human right. Based on that right, no one shall be deprived of water. In IRI, the issues of water usage and pricing are the most important in agriculture, because here around 90 percent of the water used is spent for economic needs. Thus, the methods and models of water pricing in agriculture have appointed significance. Meanwhile, water may serve as a way to ease the migration of the poor people from the mountainous regions of the IRI.

\section{Literature of Review}

Hirshleifer et al. (1960) prefer water pricing based on marginal cost, rather than average cost water pricing. They also believe difference between pricing for on-peak and off-peak demand [4].

Riordan (1971) suggests multistage marginal cost pricing technique. She finds that her proposal is able to provide 10\% - 20\% increase in total net benefits more than the typical average cost pricing techniques [5].

Dandy et al. (1984) study a water pricing method with constraint (where there are constraints on the amount of permissible price change in a charge form average cost pricing to an optimal marginal cost pricing rule). They show that such a method, which has less efficient than the optimal water pricing obtained in their study, can still raise society's benefits more than actual average cost pricing practice [6].

Johansson et al. (2000) mention that on economically efficient allocation of water causes the highest return for a certain water resource. They also suggest that to achieve this effectiveness, the price of water should be equal to sum of the marginal cost of supplying an additional unit of water and the shortage value of the resource [7].

Garcia and Reynaud (2004) mention that marginal-cost pricing (MCP) as a public utility causes maximizing social welfare. Also, in order to maximize aggregate net surplus, the famous law of equality of price and social marginal cost, and the following equation must be exist: 


$$
P=\frac{\partial C(Q)}{\partial Q}+\lambda
$$

where $\lambda$ and $Q$ show marginal shadow price of water and volume produced by a water utility respectively [8].

Huang et al. (2006) design policies that can lead to water consumption thrift in China. They find a new water policy in which by increasing water prices, direct intensives is created on water consumers to save water.

The results show that increases in water prices at the level of VMP can lead to significant water savings [9].

Cardio, A. and Calatrava, J. (2010) believe that water pricing can increase more than full supply recovery rates and charge physical consumption for water resources, as a means to ensure more efficient use (i.e. full cost recovery) in Mexico and 5 European Union countries.

The main purpose of this article is to make an empirical study of irrigation water pricing across five European Union countries where irrigation is important and Mexico, to examine irrigation water price ranges and characteristics, and also the price paid by the irrigators for water recovers operation and maintenance costs, and capital cost (i.e. renewal investment and new investment) for water delivery to the farm (i.e. full supply costs). In order to increase efficiency of water use, water pricing can rise more than full supply recovery rates and charge physical consumption for water resources (i.e. full cost recovery) [10].

Moghaddasi et al. (2009) express water pricing policy in Iran, aiming improvement in water allocation efficiency. The results show that water pricing policy has an effective role in reduction of irrigation water use. When the water price level is high, in most cases, it has higher effects than other policy scenarios in order to reduction of irrigation water use [11].

Verdi-nejad et al. (2008) calculate the water productivity (WP) for two year (2005-2006) and (2006-2007). Based on water costs and price of productions, average economic productivity of water gross profit and net profit for first period was 1060 and 419 Rials per $\mathrm{m}^{3}$ and for second period was 2392 and 666 per $^{3}$ respectively [12].

Balali et al. (2008) believe that results analysis shows that water pricing by itself can decrease considerably the demand of farmers for ground water in Baha-Hamedan Region [13].

Salami et al. (2006) believe there is a big challenge facing most of the nations including Iran in the world and that is water crisis. Exceeds of demand over supply of water has led to this crisis. Theoretically, in order to overcome this problem either an increase in supply, or decrease in demand or both, should be occurred. The results of this study after comparing the economic value of irrigation water with the calculated overage cost in ALAVIYAN dam and network, and the current price paid by the farmers shows that the economic value of water is much greater than its current price and much less than the total average cost of its utilization. This price contemplate economic, environmental, sustainability and efficiency considerations. Therefore an increase in the existing price of irrigating water seems adjustable [14].

Bagherian (2005) shows in his research that no farmers operate in optimal status and do not apply resources in the best way. Function analysis shows that farmers don't reaction to price changing in low prices. Therefore, using price instrument for diminishing water consumption is not sufficient alone and other instruments are required [15].

\section{Study Questions}

Purpose of the study is to answer the following questions:

3.1. What relation is between increasing irrigation water price and agriculture section productivity?

3.2. What differences are between productivity of several kinds of garden products?

3.3. What differences are between productivity of several kinds of tillage products?

\section{Study Method}

Study method contains all the tools and stages of collecting systematic information and the way of their rational analysis to reach to a certain purpose, which is generally to discover the facts. This study is an application-development one in terms of objective and descriptive in terms of conclusion and will answer the questions as well. Also the study is a post-event in terms of the study design and has been conducted through librarian documents and literature and also interviews. In this paper irrigation water price addition is an independent variable that is 
shown by $\mathrm{X}$ and irrigation land expansion which is shown by $\mathrm{Y}_{1}$ and money productivity which is shown by $\mathrm{Y}_{2}$ are dependent variables.

$$
Y_{1}=f(X) \& Y_{2}=f(X)
$$

\subsection{Study Population}

The study population is the farmers of Kashan Region (a city in center of Iran) who were acting from 2006 to 2010 in this region including farming or gardening, according to the following properties:

1) Had been working during the mentioned time, continually.

2) Had cultivated more than 1 Hectare land.

3) Their documents had been available in Agriculture Organization of Kashan.

\subsection{Data Collection Method}

In order to collect data, documents of agriculture organization of Kashan, librarian literature and also interviews with the farmers and experts have been used. Also since according to experts of Agriculture Organization of Kashan there are almost 3500 farmers who have above characteristics, therefore the number of sample is obtained by Cochran's formula as follow:

$$
n=\frac{N Z^{2} p q}{N d^{2}+Z^{2} p q} \Rightarrow 93=\frac{3500 \times(1.96)^{2} \times 0.5 \times 0.5}{3500 \times 0.1^{2}+1.96^{2} \times 0.5 \times 0.5}
$$

\subsection{Sampling}

In order to gathering the required information from the sample, a questionnaire in three parts including questions related to respondent's data, general questions and main questions was prepared. Through interview with 93 member of study population randomly, questionnaire were completed.

\subsection{Study Findings}

After data collection and analyzing them, the results in tables and figures are obtained.

In Table 1, according to average water use per a hectare land, the farmer in the sample are divided to 5 group. Then some data such as the number of each group, total cultivated land, and total production for 5 main product, average revenue per ton of production, total revenue in each product and average revenue per hectare have been calculated. The most average revenue per hectare is 2,395,000 Tomans which is belonged to 5th group that has used more than $14,001 \mathrm{~m}^{3}$ irrigation water per hectare land, while the average revenue is 1,639,000 in total.

Table 1 divides the study population based on average water use per hectare land. As it is shown, 93 farmers in study population have used different average amount of water in their irrigated lands. The most number of farmers in five groups are the farmers who have used from 10,001 to 12,000 $\mathrm{m}^{3}$ irrigation water per hectare land, that they are 28 farmers. But the farmers, who have used more than $14,001 \mathrm{~m}^{3}$ water per hectare land, have gained the highest average revenue per hectare that is 2,395,000 Tomans.

Table 2 shows some data about 10 main crop products which were produced by the farmers in sample during 2006-2010. As it shows the highest and the least gross product per $1 \mathrm{~m}^{3}$ are belonged to alfalfa with 11.25 and cotton with $0.36 \mathrm{~kg}$ respectively. Also dill has the highest gross income per $1 \mathrm{~m}^{3}$ with 2625 Tomans and wheat has the least with 245 Tomans.

Figure 1 shows that alfalfa has the maximum and cotton has the minimum physical productivity (the ratio of production quantity to quantity of water use) among the crops. Due to the specific shape of root and several harvests in a crop year, alfalfa has very high productivity.

Figure 2 shows that dill has the most and wheat has the lowest money productivity (the ratio of revenue from product sales to cost of water use) among the crops cultivated in the region. It means dill is more profitable than other crops.

Figure 3 shows that plum has the most and walnut has the least physical productivity among garden products.

Table 3 shows some data about 10 main garden products which were produced by the farmers in the sample during 2006-2010. As it shows the highest and the least gross product per $1 \mathrm{~m}^{3}$ irrigation water are belonged to 
Table 1. Total production \& revenue of different groups of farmers in Kashan in 5 main products.

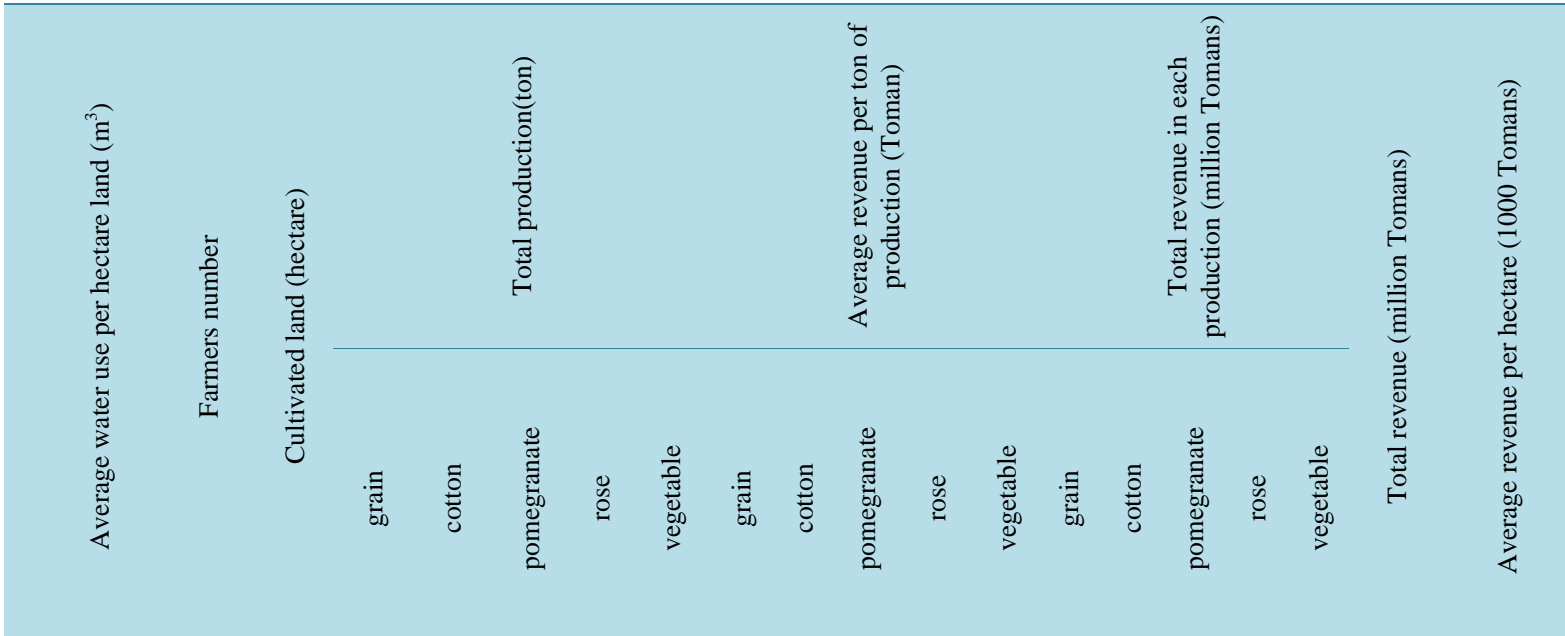

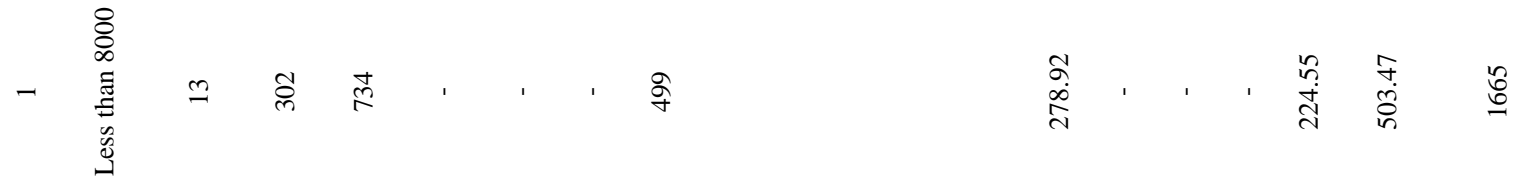

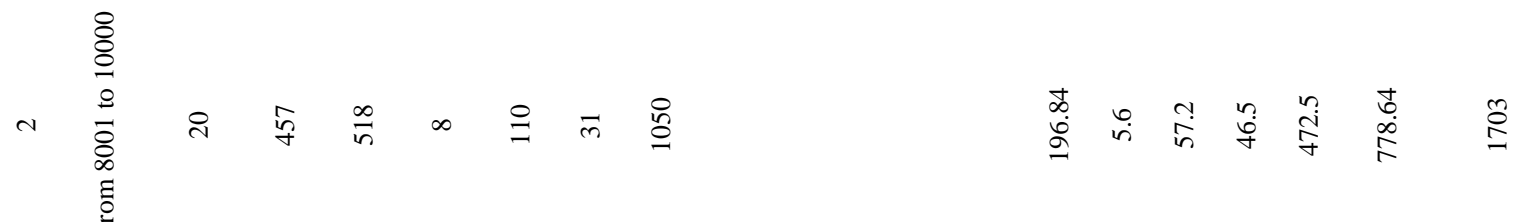

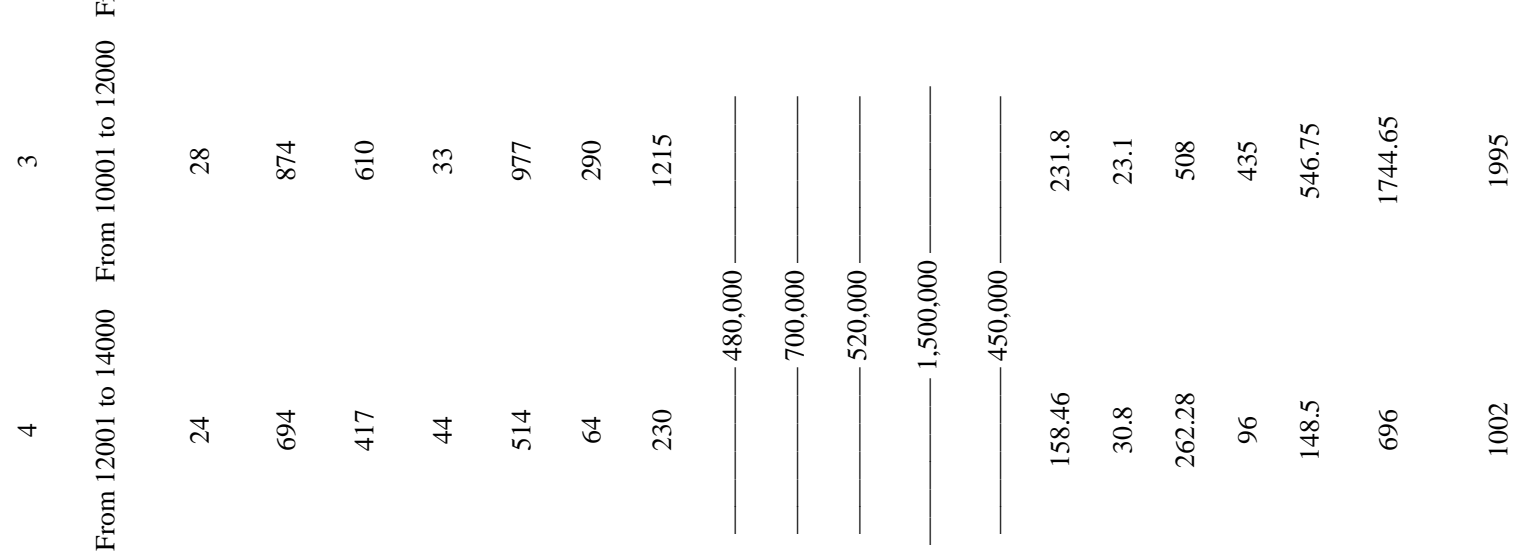

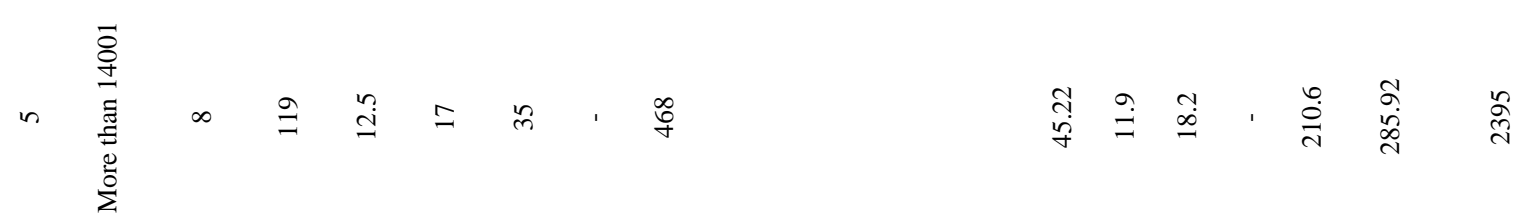

$$
\begin{aligned}
& \text { 苛 }
\end{aligned}
$$


Table 2. Irrigation water use productivity in crops.

\begin{tabular}{|c|c|c|c|c|c|c|c|c|c|c|c|}
\hline & Description & Wheat & Barley & Corn & Vegetable & Mint & Leek & Alfalfa & Onion & Cotton & Dill \\
\hline 1 & Irrigation water use $\left(\mathrm{m}^{3}\right)$ & 6840 & 5060 & 10,920 & 7820 & 17,820 & 17,850 & 17,780 & 12,900 & 13,900 & 4000 \\
\hline 2 & $\begin{array}{l}\text { Irrigation water cost } \\
\text { (1000 Tomans) }\end{array}$ & 410 & 304 & 655 & 469 & 1069 & 1071 & 1066 & 774 & 834 & 240 \\
\hline 3 & Total production (kg) & 3500 & 4000 & 8500 & 30,000 & 120,000 & 150,000 & 200,000 & 40,000 & 5000 & 35,000 \\
\hline 4 & $\begin{array}{l}\text { Total revenue } \\
\text { (1000 Tomans) }\end{array}$ & 1680 & 1600 & 5100 & 13,500 & 36,000 & 15,000 & 40,000 & 12,000 & 3500 & 10,500 \\
\hline 5 & $\begin{array}{c}\text { Revenue per } 1000 \\
\text { Tomans irrigation water } \\
\text { cost (Tomans) }\end{array}$ & 4097 & 5263 & 7786 & 28,784 & 33,679 & 14,005 & 37,523 & 15,504 & 4197 & 43,750 \\
\hline 6 & $\begin{array}{c}\text { Gross product per } 1 \mathrm{~m}^{3} \text { water } \\
\text { use }(\mathrm{kg})\end{array}$ & 0.51 & 0.79 & 0.78 & 3.83 & 6.73 & 8.4 & 11.25 & 3.1 & 0.36 & 8.75 \\
\hline 7 & $\begin{array}{l}\text { Gross income per } 1 \mathrm{~m}^{3} \\
\text { water use (Toman) }\end{array}$ & 245 & 316 & 468 & 1724 & 2019 & 840 & 2250 & 930 & 252 & 2625 \\
\hline
\end{tabular}

Table 3. Irrigation water use economic productivity in garden product.

\begin{tabular}{|c|c|c|c|c|c|c|c|c|c|c|c|}
\hline $\mathrm{h}$ & Description & Sole & Pomegranate & Apricot & Pistachio & Quince & Almond & Walnut & Grape & Rose & Plum \\
\hline 1 & $\begin{array}{l}\text { Irrigation water } \\
\text { use }\left(\mathrm{m}^{3}\right)\end{array}$ & 13,000 & 17,560 & 13,000 & 18,060 & 15,060 & 14,680 & 16,340 & 14,920 & 10,000 & 13,000 \\
\hline 2 & 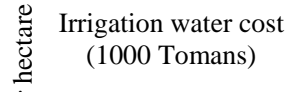 & 780 & 1054 & 780 & 1084 & 904 & 881 & 980 & 895 & 600 & 780 \\
\hline 3 & ¿ Total production (kg) & 22,000 & 30,000 & 25,000 & 3500 & 14,000 & 4500 & 3000 & 30,000 & 4000 & 30,000 \\
\hline 4 & $\begin{array}{l}\text { Total revenue } \\
\text { (1000 Tomans) }\end{array}$ & 17,600 & 15,600 & 37,500 & 10,500 & 9800 & 5400 & 7500 & 18,000 & 6000 & 24,000 \\
\hline 5 & $\begin{array}{c}\text { revenue per1000 Tomans } \\
\text { water cost (Toman) }\end{array}$ & 22,564 & 14,800 & 48,077 & 9686 & 10,840 & 6129 & 7653 & 20,111 & 10,000 & 30,769 \\
\hline 6 & $\begin{array}{c}\text { Gross product per } 1 \mathrm{~m}^{3} \\
\text { water use }(\mathrm{kg})\end{array}$ & 1.69 & 1.71 & 1.92 & 0.19 & 0.93 & 0.31 & 0.18 & 2.01 & 0.40 & 2.3 \\
\hline 7 & $\begin{array}{l}\text { Gross income per } 1 \mathrm{~m}^{3} \\
\text { water use (Toman) }\end{array}$ & 1352 & 889 & 2880 & 570 & 651 & 372 & 450 & 1206 & 600 & 1840 \\
\hline
\end{tabular}

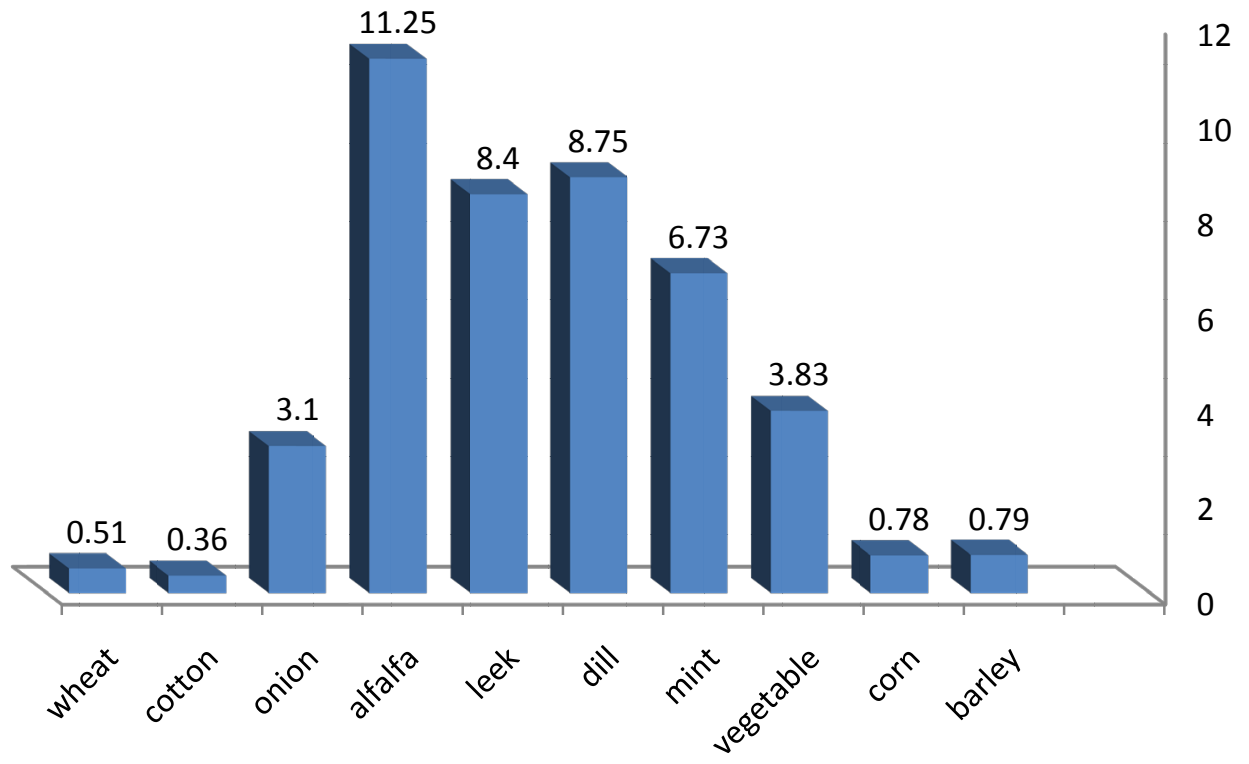

Figure 1. Physical productivity of crops. 


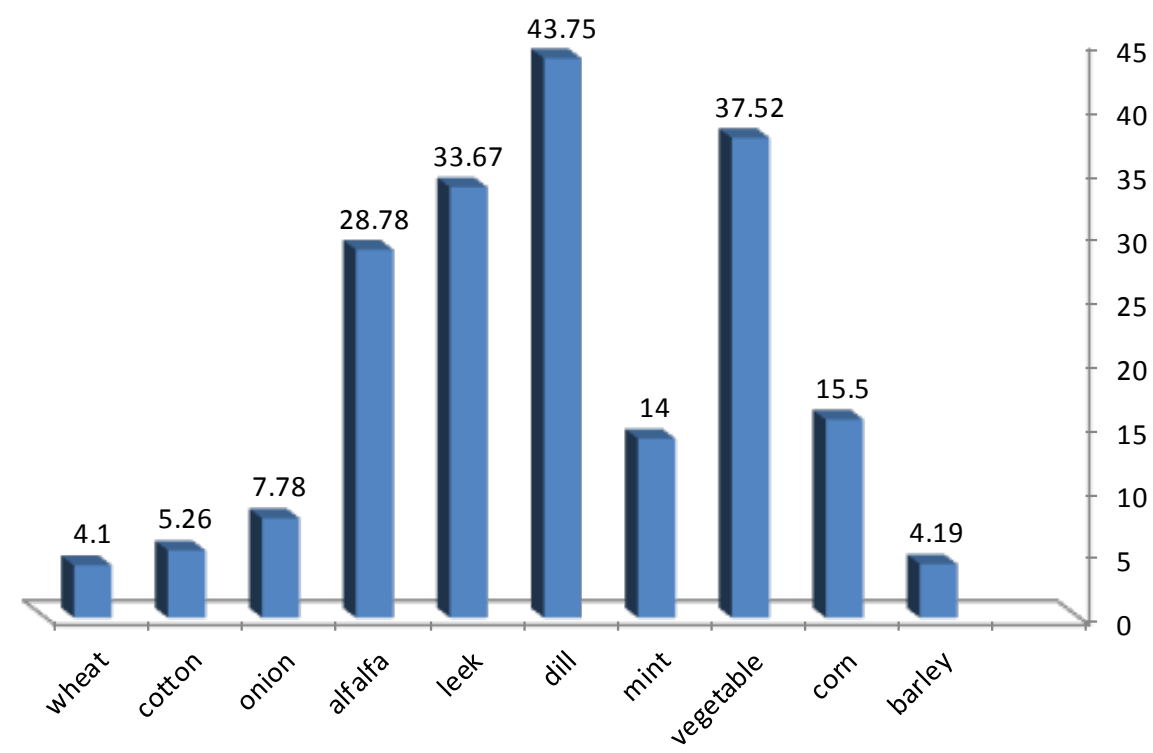

Figure 2. Crop value per 1 Toman of irrigation water (Toman).

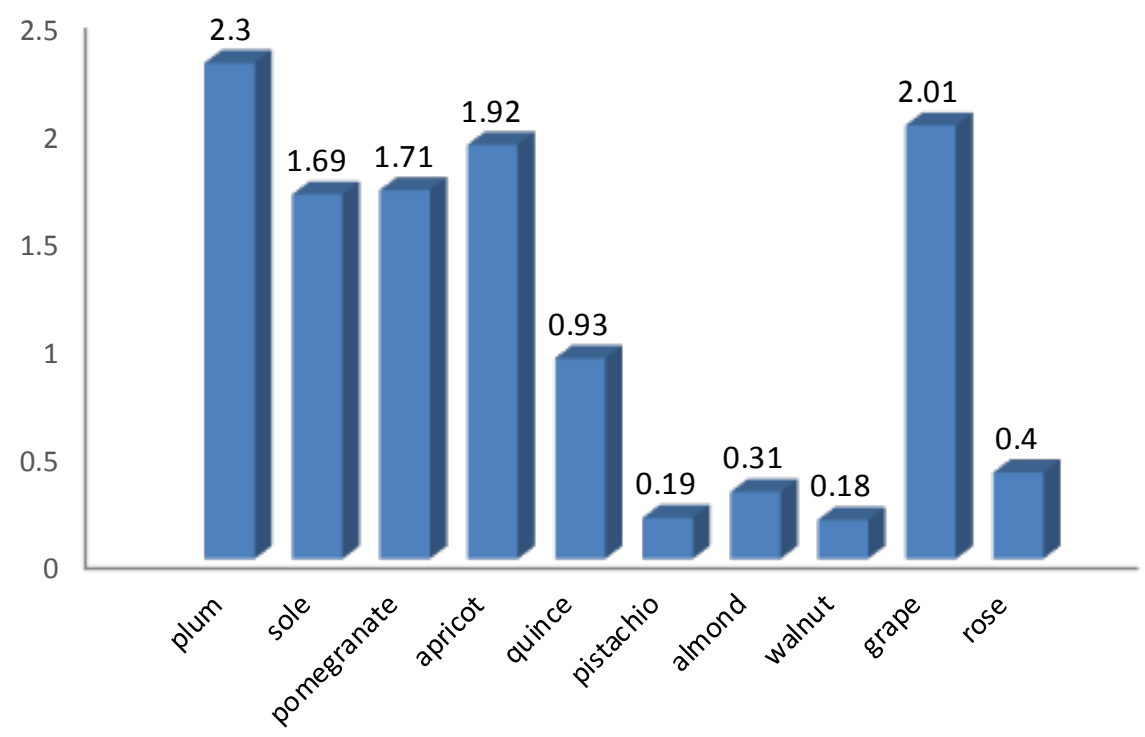

Figure 3. Garden product quantity per $1 \mathrm{~m}^{3}$ irrigation water (kg).

plum with 2.3 and walnut with $0.18 \mathrm{~kg}$ respectively. Also apricot has the highest gross income per $1 \mathrm{~m}^{3}$ irrigation water with 2880 Tomans and almond has the least with 372 Tomans.

Figure 4 shows that apricot has the highest and almond has the lowest monetary productivity.

Figure 5 shows the trend of irrigation water price during study period (2006-2010).

Figure 6 shows that during study period as irrigation water price rises, the crop value of crop per $1 \mathrm{~m}^{3}$ of irrigation water (means monetary productivity) also has increased. This indicates that crop monetary productivity has grew from 15.1 to 20.36, it means 35\% monetary productivity indication during the study period (20062010).

Figure 7 shows at first monetary productivity of garden products has decreased and then increased during the study period. One of the basic reasons of this decrease is extreme cold and frost in the region which destroys many fruit trees in January of 2007. After 2 years downward trend, it increased in 2009 and 2010.

Figure 8 shows the direct relationship between irrigation water price and area under cultivation in the region during the study period. It means irrigation water price addition not only caused the farmers leave their job, but 


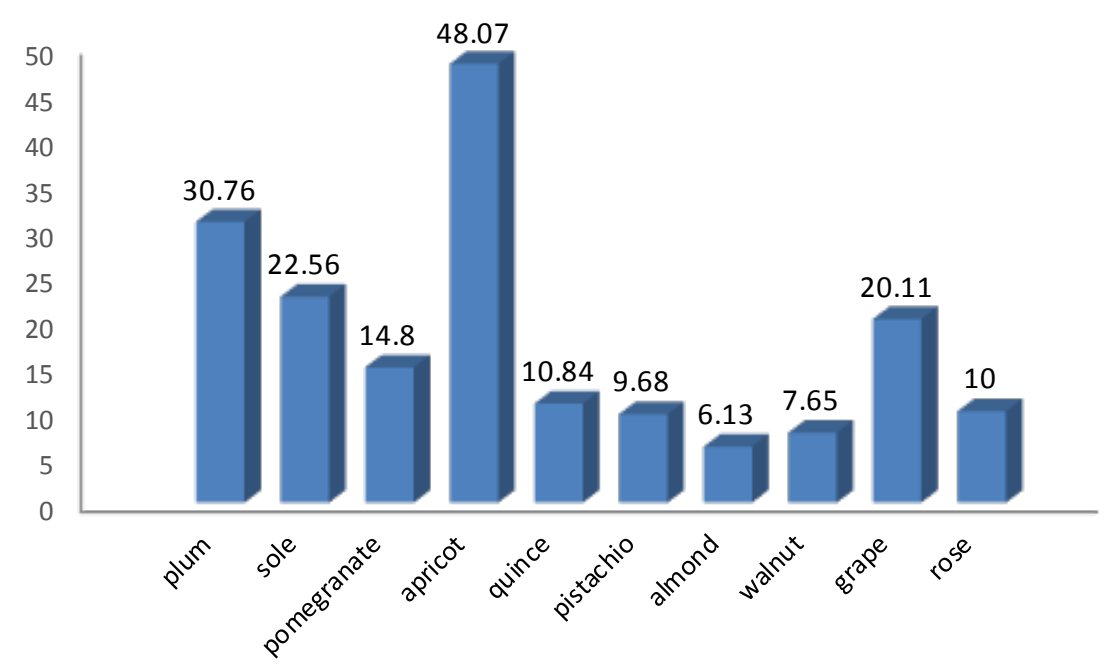

Figure 4. Garden product value per 1 Toman of irrigation water (Toman).

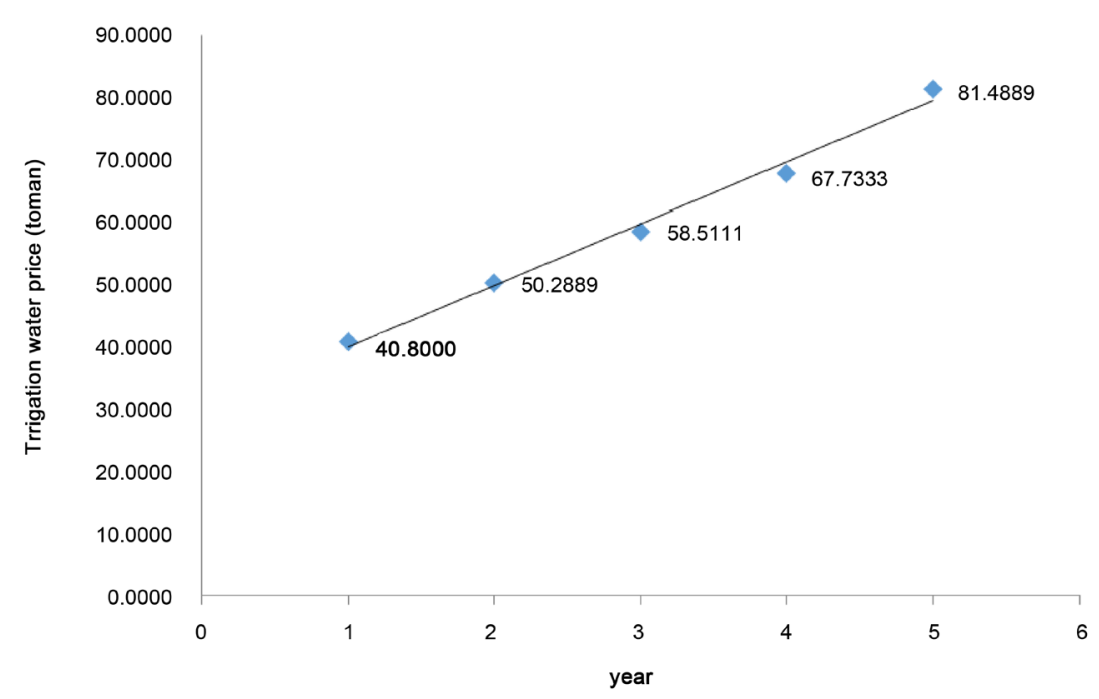

Figure 5. Irrigation water price trend during study period.

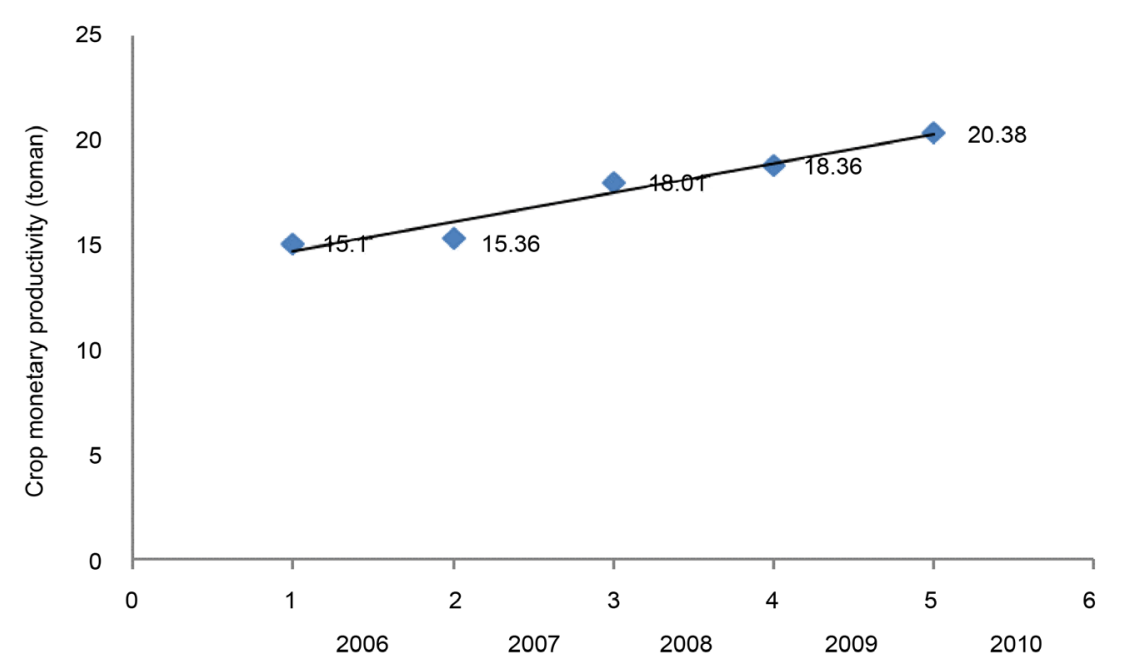

Figure 6. Crops monetary productivity trend during (2006-2010). 


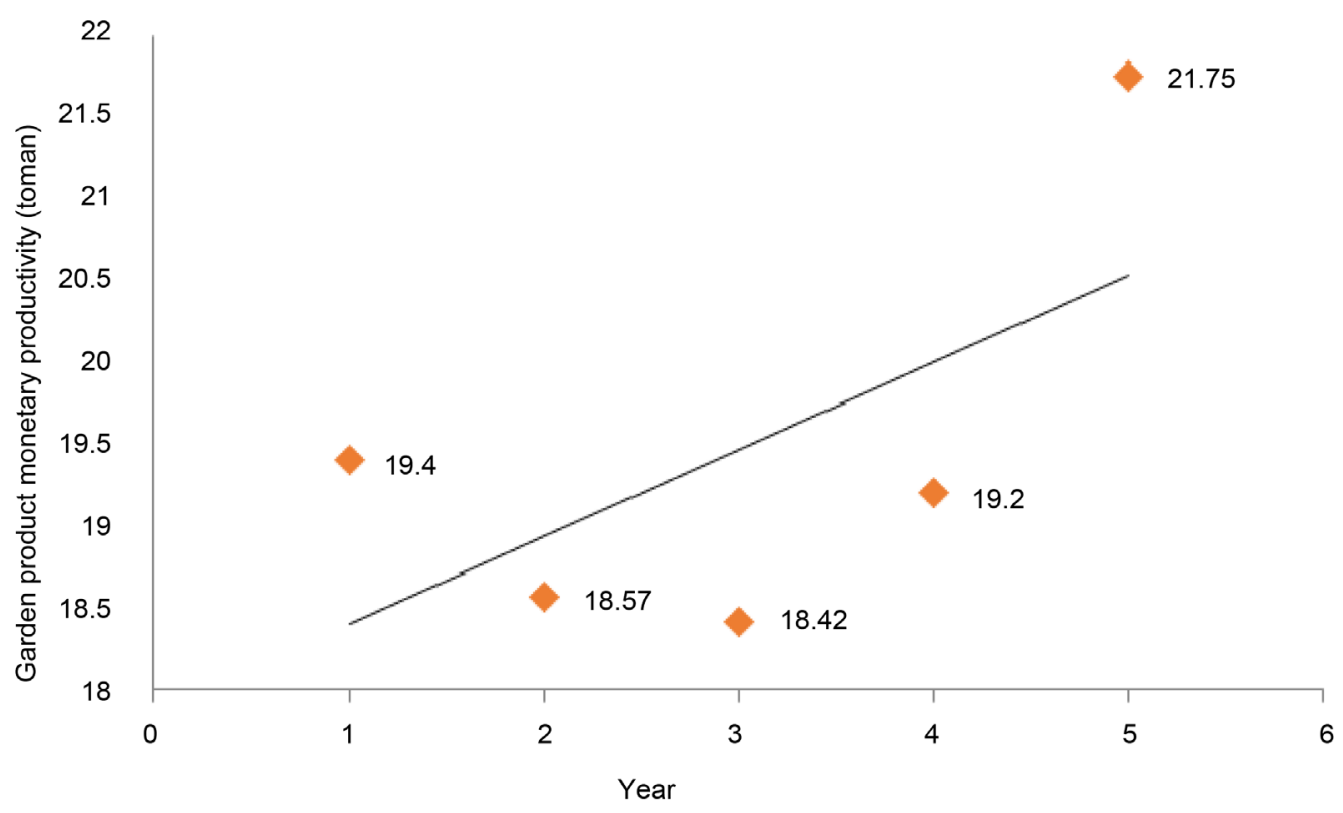

Figure 7. Garden products monetary productivity during (2006-2010).

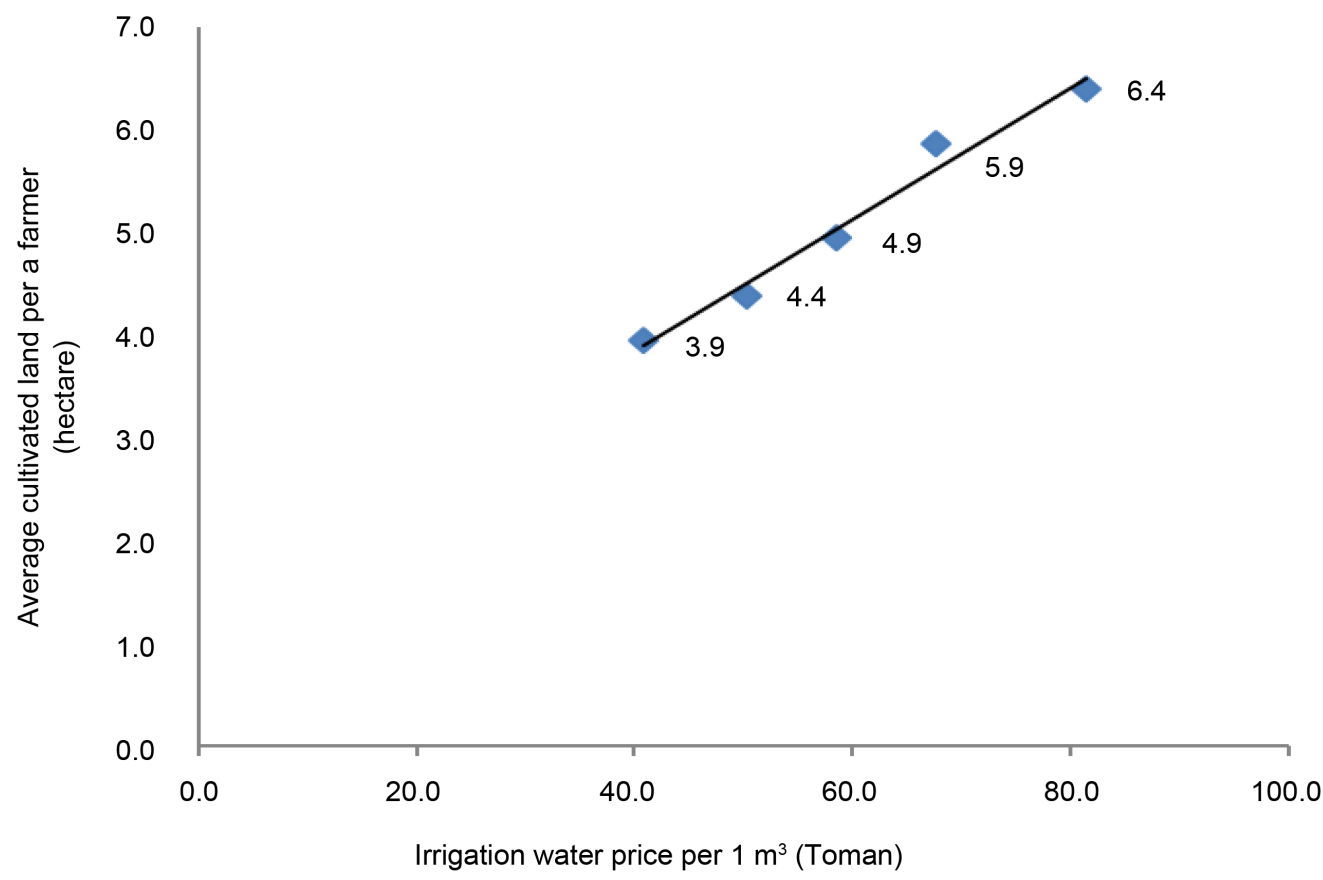

Figure 8. Average cultivated land per a farmer during the study period.

also they developed their activities.

\section{Conclusion}

As the tables and the figures show during study period, irrigation water price has raised in Kashan region. But this leads not only to increasing average cultivated land per a farmer, but also to increasing crops and garden products' monetary productivity. It means that Iranian government can use irrigation water price induction as a tool for increasing productivity in agriculture section in Iran. In addition, crops and garden products have different productivities. Results also show that dill and apricot have the highest productivity in all crops and garden 
product in the region respectively.

\section{References}

[1] Pourzand, A. (2007) Water Consumption Management; First Step for Achieving Food Security. $11^{\text {th }}$ National Committee Conference on Iran Irrigation and Drainage, 455-468.

[2] Sadate-Miraee, M.H. and Farshi, A.A. (2007) How to Use Water and Water Productivity in Agriculture Section. $11^{\text {th }}$ National Committee Conference on Iran Irrigation and Drainage, 202-213.

[3] Mamanpoosh, A. and Mousavi, S.F. (2007) Water Productivity of Irrigated Lands in Zayande Rud River Basin Network. $11^{\text {th }}$ National Committee Conference on Iran Irrigation and Drainage, 311-322.

[4] Hirshleifer, J., de Haven, J. and Milliman, J. (1960) Water Supply: Economics, Technology and Policy. University of Chicago Press, Chicago.

[5] Riordan, C. (1971) Multistage Marginal Cost Model of Investment-Pricing Decisions: Application to Urban Water Supply Treatment Facilities. Water Resources Research, 7, 463-478. http://dx.doi.org/10.1029/WR007i003p00463

[6] Dandy, G., Mc Bean, C. and Hutchinson, B. (1984) A Model for Constrained Optimum Water Pricing and Capacity Expansion. Water Resources Research, 20, 511-520. http://dx.doi.org/10.1029/WR020i005p00511

[7] Johansson, C. (2000) Pricing Irrigation Water: A Literature Survey. Policy Research Working Paper, World Bank, Washington DC.

[8] Garcia, S. and Reynaud, A. (2004) Estimating the Benefits of Efficient Water Pricing in France. Resource and Energy Economics, 26, 1-25. http://dx.doi.org/10.1016/j.reseneeco.2003.05.001

[9] Huang, Q., Rozell, S., Howitt, R., Wang, J. and Huang, J. (2006) Irrigation Water Pricing in China. IAAE Preconference.

[10] Garrido, A. and Calatrava, J. (2010) Agricultural Water Pricing EU and Mexico. Universidad Politecnica de Cartagena,

[11] Moghaddasi, R., Bakhshi, A. and Kakhaki, M.M. (2009) Analyzing the Effects of Water and Agriculture Policy Strategies: An Iranian Experience. American Journal of Agricultural and Biological Science, 4, 206-214. http://dx.doi.org/10.3844/ajabssp.2009.206.214

[12] Verdi-Nejad, V., Sohrabi, T., Heydari, N., Araghi-Nejad, S. and Mamanpoosh, A.R. (2008) Demand and Supply Survey and Agricultural Water Productivity in Zayande-Rud Basin. Journal of Irrigation and Drainage of Iran, 2, 88-99.

[13] Balali, H., Khalilian, S., Viaggi, D., Bartolini, F. and Ahmadian, M. (2008) Groundwater Balance and Conservation under Different Water Pricing and Agriculture Policy Scenarios; Case of Hamadan-Bahar Plain. Journal of Ecological Economics, 5, 863-872.

[14] Salami, H., Hossainzad, J., Sadr, K. and Liaghat, A. (2006) Determination of Appropriate Method of Water Pricing in Agricultural Section and Specification of Optimal Crop Pattern (The Case of Alavian Dam). Water Resources Management Co (WRMC).

[15] Bagherian, A. (2005) Comparing Cropping Patterns Based on Maximum Use of Land and Water. MA Dissertation, Tehran University, Tehran. 